\title{
A Study on Factors of the E-Purchasing Product Intention toward a Dynamic Vietnamese Internet Shopping
}

\author{
Chia-Nan Wang ${ }^{1}$, Dinh-Chien Dang ${ }^{1} \&$ Nguyen Van Thanh ${ }^{2}$ \\ ${ }^{1}$ Department of Industrial Engineering and Management, National Kaohsiung University of Applied Sciences, \\ Kaohsiung, Taiwan \\ ${ }^{2}$ 24h.com Convenience Join-Stock Company 157 Ly Thanh Tong, Ho Chi Minh City, Vietnam \\ Correspondence: Dinh-Chien Dang, Department of Industrial Engineering and Management, National \\ Kaohsiung University of Applied Sciences, Kaohsiung, Taiwan. E-mail: chiendktb097@gmail.com
}

Received: July 25, 2018

Accepted: August 30, 2018

Online Published: September 28, 2018

doi:10.5539/ijef.v10n10p121

URL: https://doi.org/10.5539/ijef.v10n10p121

\begin{abstract}
Vietnam in recently years is considered to be a country with rapid development of the e-commerce with a lot of online shopping sites e.g., Shoppee, Lazada, Tiki, and Adayroi. These sites provide a high variety of products from household devices to motorbike. However, Vietnamese people are still aware of risk in doing e-purchasing. They often go to tradition outlets to buy products. This study aims to investigate the antecedents of customers' intentions for the case of using Internet as a new way to purchase products in Vietnam. A research model is developed relied on the integration of theory of Technology Accepted Model and Perceived risk theory to predict customer intentions to online shopping. Five factors are included in this research: Perceived Usefulness, Perceived Ease of use, Perceived Risk, Customer's Attitude and Customer's intention. A convenience sample of 336 respondents was collected through online and offline survey. The results of this study support that exist a positive relationship between Perceived ease of use and Perceived usefulness. Attitude, in turn is positive affected by Perceived ease of use and Perceived usefulness in which Perceived ease of use has stronger influences. While perceived risk negative impacts customers' intention, perceived risk and Perceived usefulness, on the other hand, positive influences customers' intention. All hypotheses are supported. It is evident that online shoppers intention are evaluated mostly based on their attitude, perceived usefulness, perceived ease of use and perceived risk.
\end{abstract}

Keywords: E-purchasing, intention, E-commerce, products

\section{Introduction}

In Vietnam, over the last five years, in average, the amount each person spend time on Internet are raising up. Most of the time they spend for surfing, entertainment, but the number of people using this time for doing online purchasing is also considered to conduct research. Together with clothes, shoes, e-devices, home devices and a lot of kind of the products are also in the market. While Vietnam product market involves many local and foreign competitors (more than 200 brands) (Nguyen \& Sirikhoon, 2008; Phuong, 2011), customers have more selection for the same kind of product. As the result, product market is more competitive for producers to compete with each other. In the past, customers mostly require a physical check before buying products since its nature; most products were sold at stores, supermarkets Phuong (2011). However, buying products in these places often cost twice as much Phuong (2011). Therefore, both the seller and buyer seek to online shopping to gain more benefit.

Even though online shopping takes a lot advantages over traditional business, most product online buyers use online shopping as a way to gather information such as compare prices, quality, brand, find out promotion or the retailers' address... to make offline purchase (Forsythe \& Shi, 2003; Moore, n. d.). In the case of information sources, 58\% of products information comes from the Internet ASEAN Plus Inc. (2015). Moreover, since it is difficult to check the products so customer may face with the risk of fraud, counter fake, low quality, mislabeled, and smuggled products. These weaknesses become barriers to buy product online of consumers. Although these can be considered as barriers to the purchase of product online in Vietnam, there has been no academic research on the issue. 
Therefore, the main objective of this research is to find out factors affecting customer's intention to purchase product online. Practically, it is expected that the results of this research will provide better understand the antecedents of customers intention as well as strategic implication for online product vendors to enhance customer intention to online shopping in Vietnam

\section{Theoretical Foundation}

The theoretical framework of this study is based on several noticeable relevant previous studies. This study used the integration of two theories: Technology Acceptance model (Davis, Bagozzi, \& Warshaw, 1989) and customer perceived risk of online shopper (JI, Zheng, \& Chen, 2012; Lee, Tan, \& Lim, 2000; Mitchell, Davies, Moutinho, \& Vassos, 1999).

\subsection{Technology Acceptance Model (TAM)}

Davis first introduced The Technology Acceptance Model in 1989. This model is well known as an explanation and prediction the behavioral intention of users toward new technology (Li \& Huang, 2009; Chuttur, 2009). The model includes following constructs:

\section{1) Perceived usefulness (PU)}

"Usefulness" is defined as the extent to which a user believes that using the new technology will improve his or her performance in compare with not using (Davis, Bagozzi, \& Warshaw, 1989). Applied in this research context, "usefulness" is the degree which a consumer believes that purchasing product from online retailers would increase his/ her shopping effectiveness. Other researcher defined "usefulness" as the degree of someone belief that using Internet will enhance his/her performance (Moon \& Kim, 2001). More closely to this research, usefulness refers to customer's perception that using Internet will enhance their online shopping outcome (Perea y Monsuwé, Dellaert, \& De Ruyter, 2004). An application will be evaluated as high in perceived usefulness when the users realize a positive relationship between their utilization and the job performance (Davis, Bagozzi, \& Warshaw, 1989).

\section{2) Perceived ease of use (PEU)}

"Ease of use" is defined as the degree to which an individual believes that using a new technology will help them be effortless (Davis, Bagozzi, \& Warshaw, 1989). Applied into this research context "usefulness" is the degree which a consumer believes that purchase product from an online retailers would increase her shopping effectiveness (Pavlou, \& Fygenson, 2006). In other words, "Ease of use" can be used to measure how online shopping can help consumers shopping more efficient and effective (Perea y Monsuwé, Dellaert, \& De Ruyter, 2004).

\section{3) Attitude toward buying product online (ATT)}

Attitude is defined as the level of favorable or unfavorable an individual hold on specific action. A person will intend to act a specific behavior when he/she perceives it as positive and vice versa. Specifically, attitude toward purchasing product online is measured by the positive or negative evaluation of consumers toward buying product online behavior (Chiu, Lin, \& Tang, 2005).

\section{4) Intention to buy product online( INT)}

Intention is defined as an indicator to measure the willingness and effort of an individual to do or endeavor to do certain behavior. Intention to buy product online reveals the willingness of a person to buy certain kind of product or services (Li \& Huang, 2009).

\section{5) Technology acceptance model (TAM) (Davis, Bagozzi, \& Warshaw, 1989)}

In his study, Davis had shown the correlation between perceived usefulness, perceived ease of use, attitude and behavioral intention toward new technology. According to this theory, perceived of usefulness and perceived ease of use are both used to determine an individual attitude toward the new technology. The attitude and perceived usefulness in turn determines his/ her intention to use it. Last but not least, customers' perceived usefulness is positively impacted by their perceived ease of use. Thus, these factors can be used to explain the different between different customers.

Although this research is used to understand the adoption of new technology in workplace, many researches had extended and applied this model to online shopping and found out the strong correlation between this model and both of these factors are shown to be important to user's perceptions of the World Wide Web (WWW) systems. For instance, Moon and Kim also studied and extend the use of TAM in the WWW context. There work results find out that TAM is true to predict the acceptance of customer in WWW context (Moon \& Kim, 2001). Adapt 
TAM into their study, other researcher also received the similar results: compatibility, usefulness, ease of use, usefulness and security plays an important role to predict consumer's attitude toward online shopping (Eri, Islam, \& Daud, 2011). The same result is found out when applied TAM into E-commerce, TAM's construct are valuable to explain users' intention to use E-commerce (Johar \& Awalluddin, 2011).

\subsection{Perceived Risk (PR)}

In a shopping environment full of counter fake product products or products with unclear originality which account for $60 \%$ of sales like Viet Nam, perceived risk is one of the barrier consumers may concern when they are going to made online purchase decision (Cosmetics Market Brief in Vietnam). Perceived risk is defined as an individual's perception about the prospective uncertainty outcomes which can occur during the online purchase transaction. Therefore, it is necessary to integrate perceived risk into the research model

When making buying decision process, consumers often consider several kinds of risk before have the final decision. The higher level of perceived risk, the less probability that consumer will purchase these product online, the more likely that he/she will shift to traditional purchase (Moshrefjavadi, Dolatabadi, Nourbakhsh, Poursaeedi, \& Asadollahi, 2012). These kinds of risk vary from people to people but the most frequently kind of risk that customers consider when making online shopping decision involves: financial risk, product risk, convenience risk, non-delivery risk (Ariff, Sylvester, Zakuan, Ismail, \& Ali, 2014).

\subsection{Hypotheses Development}

\section{1) The relationship between Perceived ease of use and perceived of usefulness}

Perceived usefulness has been suggested that it is positively impacted by perceived ease of use. An increase in customer's perceived ease of use can directly attribute to the improvement of perceived usefulness due to the effort reduction of buyer (Davis, Bagozzi, \& Warshaw, 1989). Hence, the authors propose the following hypothesis:

H1: Perceived ease of use of product online purchase has positive influences on perceived of usefulness.

2) The relationship among perceived usefulness, perceived ease of use and attitude toward buying product online

Again, the correlation between perceived usefulness, perceived ease of use and attitude was suggested: "Attitude is jointly determined by perceived usefulness and perceived ease of use, with relative weights statistically estimated by linear regression: Attitude= Perceived usefulness + Perceived ease of use" (Davis, Bagozzi, \& Warshaw, 1989). Thus, the following hypotheses were formed:

H2: Perceived usefulness has positive influences on attitude toward buying product online.

H3: Perceived ease of use has positive influences on attitude toward buying product online.

\section{3) The relationship between Perceived risk and Customer intention to buy product online}

There exist a negative relationship between perceived risk to online shopping and intention to buy product online (JI, Zheng, \& Chen, 2012). It was argued that customers will suffer more anxiety, tension when they perceived that the risk is high which will lead to their rejection to online purchase. Other researchers also found the same results: consumers will be more inclined to buy a product if they can trust the suppliers. Further researchers found that perceived risk has significant impacts on purchase intention (Mitchell, Davies, Moutinho, \& Vassos, 1999). Therefore, the authors suggest that:

H4: Perceived risk has negative influences on behavioral intention to buy product online.

4) The relationship between Attitude toward buying product online and intention to buy product online.

If everything being equal, an individual who forms positive attitude to a new technology will consequently lead to his/her intention to use it (Davis, Bagozzi, \& Warshaw, 1989). The work of other researchers concluded that attitude is the most significant factor influencing intention (Al-Rafee \& Cronan, 2006). The same logic was observed that intention to purchase online is positive impacted by their attitude (Lim \& Ting, 2012).

Therefore, the following hypothesis is conducted:

H5: Attitude toward buying product online has positive influences on intention to buy product online.

\section{5) The relationship between Perceived usefulness and intention to buy product online}

People always create intention to a target response or behavior when they can perceive that performing certain behavior will improve their job performance. If they do not realize any sign that using this application will help to complete their job better, they are going to ignore it (Davis, Bagozzi, \& Warshaw, 1989). The same logic is 
inferred in this case, people find the task of online purchase is easy, that may increase their intention to buy product online.

H6: Perceived usefulness has positive influence on intention to buy product online.

\subsection{Research Model}

Based on the above literature review and hypothesis, an adapted research model is constructed as follows:

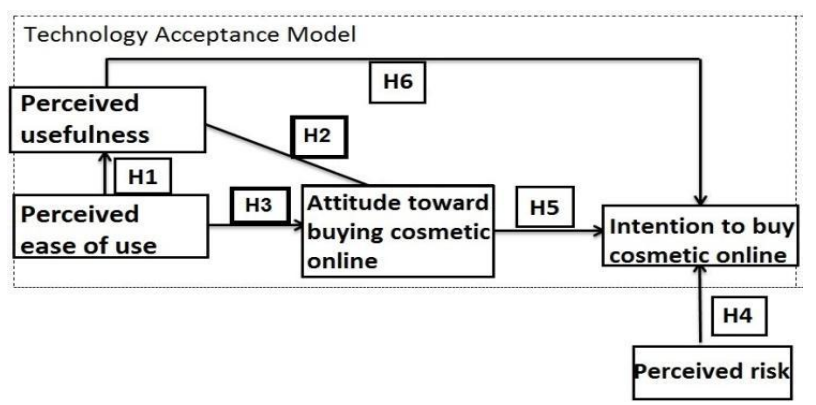

Figure 1. Research model

\section{Research Methodology}

\subsection{Research Survey}

The main context of this paper is online, so we only investigated people using Internet a lot. We conduct online survey through Google forms. Our target groups are young generation. We delivered forms in 04 months (from December, 2017 to March, 2018) to collect the target numbers. We have to spend some money for Facebook ad for this survey. Since the content of the survey is short, so we do think the data inputs are valuable to conduct a reliable research.

\subsection{Data Analysis}

In order to fulfill the requirements of this research, collected data will be analyzed by using Statistical Package for the Social Science (SPSS version 20.0) and AMOS version 20. This process is used to inspect, transforming data with the purpose to generalize and support conclusions, hypothesizes by the following test: Descriptive statistics, Reliability test, exploratory factor analysis (EFA), Confirmatory factor analysis (CFA), Structural equation modeling (SEM).

\section{Data Analysis and Finding}

\subsection{Characteristics of Sample}

Table 1 gives a short introduction about our participants in this study. There were 336 people willing to help us fulfill the requirements of the questionnaire. They are aged from 16 to larger than 30 years old and almost equivalent in gender. Interestingly, the young generation now is evolved in e-purchasing when the aged between 19-30 years old ranged at nearly $80 \%$, and most of them are students and office workers. Commonly, these numbers can reflect to the situation in Vietnam that when people know how to use Internet and online shopping, they will tend to use. As recommended, the e-purchasing and e-commerce will be potential in Vietnam when we have good policies and security from the service providers.

Table 1. Characteristics of sample

\begin{tabular}{ccc}
\hline & Frequency & Percentage \\
\hline Male & Gender & \\
Female & 176 & $52.38 \%$ \\
& 160 & $47.62 \%$ \\
\hline $16-18$ years old & Age group & $7.14 \%$ \\
$19-22$ years old & 24 & $36.61 \%$ \\
$23-30$ years old & 123 & $42.26 \%$ \\
$>30$ years old & 142 & $13.99 \%$ \\
\hline
\end{tabular}




\begin{tabular}{ccc}
\hline & Occupation & \\
\hline Pupil/ Students & 102 & $30.35 \%$ \\
Office workers & 112 & $33.33 \%$ \\
Workers & 25 & $7.44 \%$ \\
Privately-owned enterprise & 32 & $9.50 \%$ \\
Others & 65 & $19.35 \%$ \\
\hline & Monthly Income (VND) \\
\hline Under 5 million & 94 & $27.98 \%$ \\
5-under 10 million & 81 & $24.11 \%$ \\
11-under20 million & 102 & $30.36 \%$ \\
Over 20 million & 59 & $17.55 \%$ \\
Total & $\mathbf{3 3 6}$ & $\mathbf{1 0 0 . 0 0 \%}$ \\
\hline
\end{tabular}

\subsection{Reliability Testing and Exploratory Factor Analysis (EFA)}

Reliability test is conducted with the purpose checking the consistent degree of scale Bhattacherjee (2012). In this study, this consistent degree was measured through Cronbach Alpha indices and Composite Reliability. Firstly, a common rule of thumb is that a scale is good enough for conducting research in social sciences if Alpha value $>0.7$ (Hafiz \& Shaari, 2013). The Cronbach Alpha for five constructs was 0.71 or above (Table 3) suggesting that all constructs have high internal consistency. Secondly, Composite Reliability must be equal or greater than 0.7 to ensure consistent with Cronbach's alpha criteria (Fornell \& Larcker, 1981). Table 3 represents that all Composite Reliabilities are higher than 0.7. Therefore, all constructed are reliable.

\subsection{Exploratory Factor Analysis}

The current data is suitable for Exploratory Factor Analysis since its Kaiser- Meyer-Olkin (KMO) was 0.89 and Bartlett's test of Sphericity was significant $(\mathrm{p}=.000, \mathrm{df}=226)$. In the case of convergent validity, all factor loadings of each item was higher than 0.5 while the gap between each items has absolute greater than or equal 0.3 which can satisfy the requirement of discrimination validity

After reliability test and Factor Analysis, there has no items being drop out from the proposed model. There are 24 items which is extracted into five constructs:

- $\quad$ Perceived usefulness: PU1, PU2, PU3, PU4

- Perceived ease of use: PEU1, PEU2, PEU3, PEU4, PEU5, PEU6

- Perceived risk: PR1, PR2, PR3, PR4

- Attitude toward buying product online: ATT1, ATT2, ATT3, ATT4

- Intention to buy product: INT1, INT2, INT3, INT4, INT5

4.4 Confirmatory Factor Analysis (CFA)

The table below reflects the threshold of goodness- of- fit indices and its current figures of the model. It is inevitable that the model good of fit is good. All fit indices are satisfied the recommended values.

Table 2. Model fit of CFA

\begin{tabular}{lcc}
\hline Fit indices & Recommended fit indices Duy, N. K. (2009) & Current fit indices \\
\hline CMIN/df & $<5$ & 1.808 \\
CFI & $>0.9$ & 0.938 \\
TLI & $>0.9$ & 0.929 \\
RMSEA & $<0.06:$ good fit & 0.054 \\
AGFI & $>0.8$ & 0.856 \\
SRMR & $<0.09$ & 0.0539 \\
PCLOSE & $>0.05$ & 0.198 \\
\hline
\end{tabular}

\subsubsection{Convergent Validity}

The convergent validity is achieved if factor loading for each item greater than or equal 0.5 and Average Variance extracted( AVE) greater than 0.5. Firstly, all factors loading are ranging from 0.635 to 0.851 (Table 4). The two lowest AVE is Perceived usefulness and Perceived ease of use (0.492 and 0.498, respectively) (Table 3). 
These number, however are high approximately to 0.5. Other AVEs are greater than 0.5. These figures suggest a good convergent validity.

Table 3. Reliability testing and convergent validity

\begin{tabular}{|c|c|c|c|c|c|}
\hline & Items & Factor loadings & AVE & Cron-bach Alpha & $\mathrm{CR}$ \\
\hline \multirow{6}{*}{$\begin{array}{c}\text { Perceived ease of } \\
\text { use }\end{array}$} & PEU3 & 0.689 & \multirow{6}{*}{0.498} & \multirow{6}{*}{0.821} & \multirow{6}{*}{0.856} \\
\hline & PEU4 & 0.711 & & & \\
\hline & PEU1 & 0.673 & & & \\
\hline & PEU2 & 0.721 & & & \\
\hline & PEU6 & 0.732 & & & \\
\hline & PEU5 & 0.705 & & & \\
\hline \multirow{5}{*}{$\begin{array}{l}\text { Intention to buy } \\
\text { product online }\end{array}$} & INT1 & 0.821 & \multirow{5}{*}{0.621} & \multirow{5}{*}{0.801} & \multirow{5}{*}{0.891} \\
\hline & INT2 & 0.851 & & & \\
\hline & INT3 & 0.746 & & & \\
\hline & INT4 & 0.747 & & & \\
\hline & INT5 & 0.77 & & & \\
\hline \multirow{5}{*}{ Attitude } & ATT3 & 0.747 & \multirow{5}{*}{0.568} & \multirow{5}{*}{0.826} & \multirow{5}{*}{0.868} \\
\hline & ATT2 & 0.748 & & & \\
\hline & ATT4 & 0.781 & & & \\
\hline & ATT5 & 0.754 & & & \\
\hline & ATT1 & 0.737 & & & \\
\hline \multirow{4}{*}{ Perceived risk } & PR1 & 0.77 & \multirow{4}{*}{0.556} & \multirow{4}{*}{0.792} & \multirow{4}{*}{0.833} \\
\hline & PR2 & 0.771 & & & \\
\hline & PR3 & 0.724 & & & \\
\hline & PR4 & 0.716 & & & \\
\hline \multirow{4}{*}{$\begin{array}{l}\text { Perceived } \\
\text { usefulness }\end{array}$} & PU2 & 0.778 & \multirow{4}{*}{0.492} & \multirow{4}{*}{0.711} & \multirow{4}{*}{0.794} \\
\hline & PU1 & 0.701 & & & \\
\hline & PU3 & 0.635 & & & \\
\hline & PU4 & 0.685 & & & \\
\hline
\end{tabular}

\subsubsection{Check Discriminator Validity}

The discrimination validity of each construct can be measured through the following indices and thresholds:

- $\quad$ AVE $>r^{2}$

- $\quad$ Maximum Shared Variance (MSV) $<$ AVE

- $\quad$ Average Shared Variance (ASV) $<$ AVE

The below results reflect that all criteria are met. Therefore, the discrimination is achieved.

Table 4. Discriminator validity

\begin{tabular}{lccccc}
\hline & PR & PEU & INT & ATT & PU \\
\hline PR & $\mathbf{0 . 5 5 6}$ & & & & \\
PEU & 0.000 & $\mathbf{0 . 4 9 8}$ & & & \\
INT & 0.082 & 0.178 & $\mathbf{0 . 6 2 1}$ & & \\
ATT & 0.017 & 0.272 & 0.476 & $\mathbf{0 . 5 6 8}$ & \\
PU & 0.026 & 0.195 & 0.342 & 0.255 & $\mathbf{0 . 4 9 2}$ \\
\hline
\end{tabular}

Note. Diagonal represents the Average Variance extracted while the other matrix entries represent the squared correlation.

Table 5. Shared variance indices

\begin{tabular}{llllll}
\hline & PEU & INT & ATT & PT & PU \\
\hline AVE & $\mathbf{0 . 4 9 8}$ & $\mathbf{0 . 6 2 1}$ & $\mathbf{0 . 5 6 8}$ & $\mathbf{0 . 5 5 6}$ & $\mathbf{0 . 4 9 2}$ \\
MSV & 0.27 & 0.48 & 0.48 & 0.08 & 0.34 \\
ASV & 0.16 & 0.27 & 0.26 & 0.03 & 0.21 \\
\hline
\end{tabular}

Note. $\mathrm{MSV}=$ Maximum Shared Variance, ASV= Average Shared Variance. 
4.5 Structural Equation Model Analysis (SEM)

\subsubsection{Hypotheses Test}

Table 6. Hypotheses testing in SEM

\begin{tabular}{lllllll}
\hline & & & & Estimate & P & Resulted \\
\hline 1 & PU & $<---$ & PEU & 0.504 & $* * *$ & Supported \\
2 & ATT & $<---$ & PU & 0.3 & $* * *$ & Supported \\
3 & ATT & $<---$ & PEU & 0.379 & $* * *$ & Supported \\
4 & INT & $<---$ & PR & -0.183 & $* * *$ & Supported \\
5 & INT & $<---$ & ATT & 0.601 & $* * *$ & Supported \\
6 & INT & $<---$ & PU & 0.305 & $* * *$ & Supported \\
\hline
\end{tabular}

Note. $* * *$ indicates p-value $<0.01$.

PU= Perceived Usefulness, PEU= Perceived ease of use; PR= Perceived risk; ATT= Attitude toward buying product online, INT=Intention to buy product online.

As can be seen from the SEM result, all paths are significant since its p-value are both less than 0.05.Six hypotheses were also supported.

The study results confirmed the positive relation between Perceived ease of use and perceived usefulness $(\beta=$ 0.504; $\mathrm{p}<0.01)$. Therefore, $\mathrm{H} 1$ is supported. As it is expected, there is a positive relation between Perceived usefulness and attitude toward buying product online $(\beta=0.3 ; p<0.01)$. Thus, $\mathrm{H} 2$ is confirmed. The same result was found on the relationship between Perceived ease of use and Attitude toward buying product online ( $\beta$ $=0.379, \mathrm{p}<0.01) \cdot \mathrm{H} 3$ is also supported. Perceived risk was found has negative influences on Intention to buy product online $(\beta=-0.813, \mathrm{p}<0.01)$. $\mathrm{H} 4$ is supported. Intention to buy product online is strong influenced by attitude toward buying product online $(\beta=0.601, \mathrm{p}<0.01)$ while Perceived usefulness has a smaller influences $(\beta=$ $0.305, \mathrm{p}<0.01) \mathrm{H} 5, \mathrm{H} 6$ are confirmed.

The $\mathrm{R}^{2}$ for Customer intention, attitude and perceived usefulness were $0.57,0.37$ and 0.2 reflecting that the model provides strong explanations of the variance in customer intention, attitude and perceived usefulness.

\subsubsection{Check for Model Fit}

Chi-squared of this model is 304.536 degree of freedom is 165 with p-value $=0.000$. The value of Chisquare/degree of freedom is less than 5 which is approximately 1.808 . More to the point, order indices also fit well: $\mathrm{CFI}=0.936$, TLI=0.929, AGFI $=0.856$. All of these indices are closely to 0.9. RMSEA numerator is good fit because this number is less than 0.06 . Therefore, it can be accepted that the model has a good fit.

\section{Finding and Conclusion}

\subsection{Discussions of Results and Implications}

This research gives the authors empirical evidences to confirm the roles of customers' attitude, perceived usefulness and perceived risk on customers' intention as well as the roles of perceived usefulness and perceived ease of use as antecedents of attitude. It can be recognized from this study that attitude, perceived risk and customer perceived usefulness have positive impact on the intention of customers. On the other hand, perceived ease of use, perceived usefulness was founded to have a positive impact on customer's attitude. Customers' experiences about the transaction process, the effort they must spend and the ability to buy certain product are extremely important to form positive attitude of consumers Customers' perceived usefulness is also influenced by perceived ease of use. The more customers perceived buying products online as something easy, the more useful they perceived. In summary, a consumer who evaluate buying product online as useful, easy, low risk will form a favorable attitude and more willing to buy product online.

This study recommends the following managerial implications:

- Website: In order to keep the buying products process easy and flexible it is necessary for online vendors to adjust the layout and content of their selling tools (websites, fan page ....) to be user- friendly and match the preference of the target consumers. Moreover, contents of website should be arranged approximately so customer can find what they want fast and easily. Help and assistance tools, live customers support and chat room are essential remedies for this issue. Furthermore, online retailers should concentrate on developing effective guidance such as video clip to tutor for consumers who are not familiar with online shopping Consumers are also face the risk of receiving products different from the described products they saw on the 
Internet. It is wise to give consumers more information about each product as much as real such as provide video or 3D image so consumers can imagine these products easily. In order to make customer feel buying product online useful, retailer should improve customers shopping performance and productivity, a list of products should be provided on a sidebar so customer can focus on their goal, avoid distractions which would reduce their shopping productivity (Lim \& Ting, 2012).

- Delivery Service: In order to save time of consumer for shopping, the web retailers should not ignore the important of delivery service which directly increase customers' convenient and then improve their productivity. Customers may fear that their products will be distorted or damaged due to the carelessness of shippers. Therefore online vendors need to deal with a prestige shipping service providers.

- Payment: Online vendors should pay more attention to financial risk by developing a special type of credit card which are separated from their bank accounts or allow payment after delivery which will motivate consumers and reduce their fear

\subsection{Limitations and Recommendation for Future Research}

It is impossible to avoid limitations in each study. The first restriction comes from the demographics characteristics of sample. Most of respondents are student with low to middle income. Therefore, the research results might be biased toward this group. Next, even though the recommended research model has find out the relationship between these variables, it is still necessary to conduct a research to find out more variables which can predict customer intention better

\section{References}

Al-Rafee, S., \& Cronan, T. P. (2006). Digital piracy: Factors that influence attitude toward behavior. Journal of Business Ethics, 63(3), 237-259. https://doi.org/10.1007/s10551-005-1902-9

Ariff, M. S. M., Sylvester, M., Zakuan, N., Ismail, K., \& Ali, K. M. (2014). Consumer Perceived Risk, Attitude and Online Shopping Behaviour; Empirical Evidence from Malaysia. IOP Conference Series: Materials Science and Engineering, 58(1). https://doi.org/10.1088/1757-899X/58/1/012007

ASEAN Plus Inc. (2015). Cosmetic Survey among Vietnamese.

Bhattacherjee, A. (2012). Social science research: principles, methods, and practices.

Phuong, P. T. (2011). An Empirical Study on Consumer Intention for Cosmetics in Vietnam Based on the Theory of Planned Behavior (pp. 1-58). Doctoral dissertation.

Chiu, Y. B., Lin, C. P., \& Tang, L. L. (2005). Gender differs: assessing a model of online purchase intentions in e-tail service. International Journal of Service Industry Management, 16(5), 416-435. https://doi.org/10.1108/09564230510625741

Chuttur, M. Y. (2009). Overview of the technology acceptance model: Origins, developments and future directions. Working Papers on Information Systems, 9(37), 9-37.

Cosmetics Market Brief in Vietnam. Retrieved from http://www.globaltrade.net/f/business/text/Vietnam/Cosmetics-Hairdressing-Beauty-TreatmentHairdressing-Beauty-Treatment-Cosmetics-Market-Brief-in-Vietnam.html

Davis, F. D., Bagozzi, R. P., \& Warshaw, P. R. (1989). User acceptance of computer technology: A comparison of two theoretical models. Management Science, 35(8), 982-1003. https://doi.org/10.1287/mnsc.35.8.982

Duy, N. K. (2009). Thựchànhmôhìnhcấutrúctuyếntính SEM vớiphầnmềm AMOS. TruờngĐạihọcKinhtế TPHCM, 2009.

Eri, Y., Islam, M. A., \& Daud, K. A. K. (2011). Factors that influence customers' buying intention on shopping online. International Journal of Marketing Studies, 3(1), 128. https://doi.org/10.5539/ijms.v3n1p128

Fornell, C., \& Larcker, D. F. (1981). Evaluating structural equation models with unobservable variables and measurement error. Journal of Marketing Research, 39-50. https://doi.org/10.2307/3151312

Forsythe, S. M., \& Shi, B. (2003). Consumer patronage and risk perceptions in Internet shopping. Journal of Business Research, 56(11), 867-875. https://doi.org/10.1016/S0148-2963(01)00273-9

Hafiz, B., \& Shaari, J. A. N. (2013). Confirmatory factor analysis (CFA) of first order factor measurement model-ICT empowerment in Nigeria. International Journal of Business Management and Administration, 2(5), 81-88.

Ho, T. H. L., \& Chen, Y. (2014). Vietnamese Consumers' Intention to Use Online Shopping: The Role of Trust. 
International Journal of Business and Management, 9(5), 145.

JI, S. X., Zheng, X., \& Chen, D. (2012). Perceived Risk and Its Impact on Customer Intention to Online Shopping Based-on Different Products. Advances in Information Sciences \& Service Sciences, 4(17).

Johar, M. G. M., \& Awalluddin, J. A. A. (2011). The role of technology acceptance model in explaining effect on e-commerce application system. International Journal of Managing Information Technology, 3(3), 1-14. https://doi.org/10.5121/ijmit.2011.3301

Lee, K. S., Tan, S. J., \& Lim, G. H. (2000). E-retailing: Success factors for entrepreneurial start-ups. Faculty of Business Administration, National University of Singapore, Singapore.

Li, Y. H., \& Huang, J. W. (2009). Applying theory of perceived risk and technology acceptance model in the online shopping channel. World Academy of Science, Engineering and Technology, 53(1), 919-925.

Lim, W. M., \& Ting, D. H. (2012). E-shopping: An Analysis of the Technology Acceptance Model. Modern Applied Science, 6(4), 49. https://doi.org/10.5539/mas.v6n4p49

Mitchell, V. W., Davies, F., Moutinho, L., \& Vassos, V. (1999). Using neural networks to understand service risk in the holiday product. Journal of Business Research, 46(2), 167-180. https://doi.org/10.1016/S01482963(98)00020-4

Moon, J. W., \& Kim, Y. G. (2001). Extending the TAM for a World-Wide-Web context. Information \& Management, 38(4), 217-230. https://doi.org/10.1016/S0378-7206(00)00061-6

Moore. B2C Commerce- Ngườitiêu dung vàhoạtđộngquảngcáotrựctuyến.

Moshrefjavadi, M. H., Dolatabadi, H. R., Nourbakhsh, M., Poursaeedi, A., \&Asadollahi, A. (2012). An analysis of factors affecting on online shopping behavior of consumers. International Journal of Marketing Studies, 4(5), 81. https://doi.org/10.5539/ijms.v4n5p81

Nguyen, H. M., \& Sirikhoon, S. (2008). Cosmetic market in Vietnam. School of Sustainable Development of Society and Technology, Mälardalen University, Västerås.

Pavlou, P. A., \& Fygenson, M. (2006). Understanding and predicting electronic commerce adoption: An extension of the theory of planned behavior. MIS Quarterly, 115-143. https://doi.org/10.2307/25148720

Perea y Monsuwé, T., Dellaert, B. G., \& De Ruyter, K. (2004). What drives consumers to shop online? A literature review. International Journal of Service Industry Management, 15(1), 102-121. https://doi.org/10.1108/09564230410523358

Teo, T. S., \& Liu, J. (2007). Consumer trust in e-commerce in the United States, Singapore and China. Omega, 35(1), 22-38. https://doi.org/10.1016/j.omega.2005.02.001

\section{Appendix}

\begin{tabular}{|c|c|}
\hline $\begin{array}{l}\text { Perceived usefulness } \\
\text { Davis, F. D., Bagozzi, R. } \\
\text { P., \& Warshaw, P. R. } \\
(1989)\end{array}$ & $\begin{array}{l}\text { 1. Purchase product via Internet will help me purchase more quickly } \\
\text { 2.Purchase product via Internet will make it is easier to shopping } \\
\text { 3. I find that online shopping useful for my shopping } \\
\text { 4. Overall, I find purchasing product online is useful }\end{array}$ \\
\hline $\begin{array}{l}\text { Perceived ease of use } \\
\text { Davis, F. D., Bagozzi, R. } \\
\text { P., \& Warshaw, P. R. } \\
\text { (1989) }\end{array}$ & $\begin{array}{l}\text { 1. Learning to purchase product online would be easy for me } \\
\text { 2. I would find purchase product online flexible to interact with } \\
\text { 3. It would be easy for me to become skillful at purchasing product online } \\
\text { 4. My interaction to purchase product online is clear and understandable } \\
\text { 5. I would find it is easy to buy what I want by online shopping } \\
\text { 6. Overall, I find purchase product online is easy to use }\end{array}$ \\
\hline $\begin{array}{l}\text { Perceived risk Teo, T. S., } \\
\text { \& Liu, J. (2007) }\end{array}$ & $\begin{array}{l}\text { 1. I believed that the risk of purchasing product online is very high } \\
\text { 2. There is high probability of losing a great deal by purchasing product online } \\
\text { 3. There is great deal uncertainty associated with purchasing online } \\
\text { 4. Overall I would label the option of purchasing product online as something negative }\end{array}$ \\
\hline $\begin{array}{l}\text { Attitude Ho, T. H. L., \& } \\
\text { Chen, Y. (2014) }\end{array}$ & $\begin{array}{l}\text { 1. Using Internet for purchase product is a good idea } \\
\text { 2. Using Internet for purchase product is a wise idea } \\
\text { 3. Using Internet for purchase product is pleasant idea } \\
\text { 4. Using Internet for purchase product is a positive idea } \\
\text { 5. Using Internet for purchase product is an appealing idea }\end{array}$ \\
\hline
\end{tabular}


1. I will keep purchase product online in the future

Customer intention Teo, 2. I will keep purchase product online as a shopping medium in the future

T. S., \& Liu, J. (2007) 3. I will keep to purchase product online rather than traditional business in the future

4. I will recommend others to use online shopping

5. I will frequently purchase product online in the future

\section{Copyrights}

Copyright for this article is retained by the author(s), with first publication rights granted to the journal.

This is an open-access article distributed under the terms and conditions of the Creative Commons Attribution license (http://creativecommons.org/licenses/by/4.0/). 